\title{
VIRTUAL INITIATION OF PERSONS IN LATE ADULTHOOD - FROM CLASSROOM/LESSON EDUCATION TO GAMIFICATION
}

\author{
EWA JURCZYK-ROMANOWSKA \\ Institute of Pedagogy, University of Wrocław \\ J. Wł. Dawida 1, 50-527 Wrocław, Poland \\ E-mail address: ewa.jurczyk@uni.wroc.pl
}

\begin{abstract}
With the development of Information and Communication Technologies one can observe the phenomenon of e-exclusion of certain social groups. Among them there are the persons in late adulthood who for various reasons do not use computers or the internet. The causes of this can be located in the low financial status of this social group. At the same time, the argument is raised that the more important problem is the lack of motivation and the number of obstacles that seniors face in their access to ICT. The paper presents the conclusions from the research conducted with the Avec Association and the Games and Innovation in Education Research Team - Edutainment (Zespół Badawczy Gier i Innowacji w Edukacji - Edutainment). This encompasses, on the one hand, problems pertaining to seniors' motivation, the obstacles that they face, their perception of the virtual world, and on the other, the description of the search for new educational methods that may make it possible to increase the effectiveness of computer skills training courses.
\end{abstract}

Key words: virtual world, e-exclusion, education of seniors, location-based games, gamification, motivation, obstacles in access to ICT

We are now entering a period unknown in history so far; a period when young people become unique authorities in the pre-figurative understanding unheard of in the past

(Mead, 2000, p. 23).

\section{INTRODUCTION}

When Margaret Mead divided cultures into post-figurative, co-figurative, and pre-figurative (Mead, 2000, p. 23) the world entered a new era. The Advanced Research Projects Agency Network (ARPANET) project was successful (Weber, 2009) which resulted in the construction of a worldwide computer web - the Internet, along with it a dynamic development of Information 
and Communication Technologies (ICT). These are defined as "a combination of telecommunication, computers, interface programmes, and data systems that support, store, and transfer integrated communication between systems" (Murray, 2011), or, to put it simply, "the technology used to handle information and aid communication" (Free On-Line Dictionary of Computing, 2008). ICT has become a substrate of the Information Society (IS). As Tomasz Goban-Klas and Piotr Sienkiewicz point out, "it is a society in which it is not direct contacts (...) but contacts through media that constitute the dominant form of social contacts" (Goban-Klas, \& Sienkiewicz, 1999, pp. 42-47). These authors also discuss the prevalent role of ICT in human communication. This definition is compatible with the one presented in a report by the IBM Community Development Fundation, according to which information society is characterised by a high level of information intensity in the everyday life of most citizens, in most organisations and workplaces; by the use of common or compatible technology for a wide range of personal, social, educational and business activities; and by the ability to transmit and receive digital data rapidly between places irrespective of distance" (Habib, J., Harris, K., Hellawell, S., Mattews, D., Percy-Smith, J., Taylor, J., \& Thompson, B., 1997). This denotes substantial quantitative as well as qualitative changes caused by technological progress. One of the consequences of this progress is the phenomenon of the digital divide (e-exclusion), which means that the lack of ICT skills makes it impossible to fully participate in social life.

As can be concluded from the Social Diagnosis 2013 (Czapiński, \& Panek, 2014) non-family single- and multi-person households have the lowest level of access to computers. Dominik Batorski recapitulates: “Access to computers and the Internet in households depends to a major extent on the type of the family. Over $90 \%$ of married couples with children have a computer, and an insignificantly lower number of them have Internet access. On the other end of the spectrum there are single-person households in which computers and the Internet are available significantly more rarely - only one in three people living alone have Internet access. [...] Married couples with no children also have a lower than average Internet access - 57\%. In the case of both of these groups the lower presence of technology is connected with the fact that most of them are households comprised of seniors" (Batorski, 2014, p. 362). What is more, the access to ICT increases with income per capita in a family.

\section{COMPUTER SKILLS TRAINING FOR SENIORS}

Digitalisation and the age of its beneficiaries. According to Batorski: "the fundamental causes of the lack of new technologies in households are motivational and psychological, rather than financial or technological" (Batorski, 2014, p. 364). Furthermore: "the reason for not using the Internet in such a numerous group of people [over $40 \%$ - E.J.R.] who have such access is the lack 
of the necessity for such use and a lack of the necessary competences. What also ought to be noted is that these people are not "cut off" from the Internet. They do have contact with it to a certain extent and they do use it with the help of other members of the household, when they ask them to find information that they need or to send a message, etc." (Batorski, 2014, p. 367).

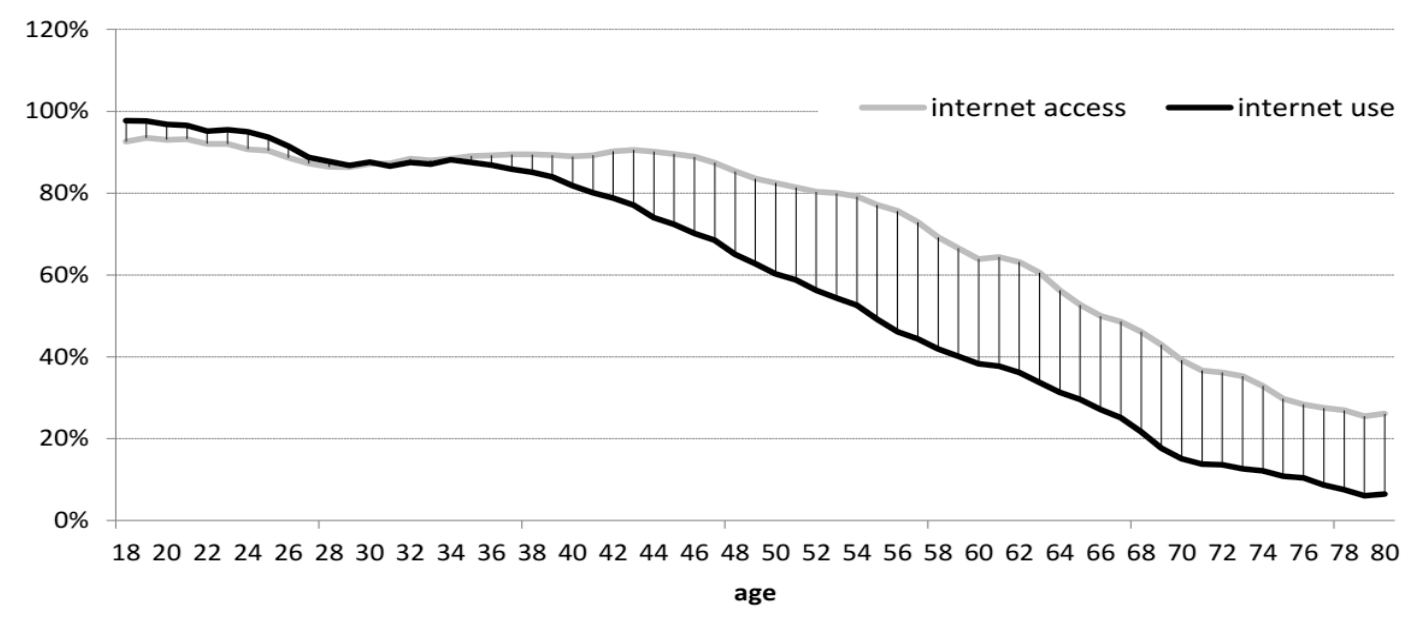

Fig. 1 Access to the Internet and Internet usage by persons of different ages; source (Batorski, 2014, p. 367).

According to the above figure (fig. 1) the access and the usage of the Internet are closely connected with the users' age. After 50 years of age the percentage of the people that have ICT in their home and who use them drops rapidly. What is more, to a large extent seniors fail to make use of Internet access even if they do have it. Statistical analyses have shown that only a small percentage of seniors use the Internet (14\% of those aged 65 or more) (Batorski, 2014, p. 368). Furthermore, on the basis of a comparison with the diagnoses from previous years it can be concluded that: "The differences in the use of the Internet related to age are great and there is no indication of a decrease [...] The intergenerational differences in Internet usage are a source of a number of negative social phenomena. The more the Internet becomes the main, or the exclusive, source of information on numerous aspects of life, the more it is difficult for the persons who do not use it to achieve access to this information. This pertains not only to professional activities, but also to participation in social and cultural life. The Internet is not only a means of access to information, but it is also indirectly a means of participation and activity outside the web" (Batorski, 2014, pp. 368-369). When analysing other factors apart from age one may learn that people with lowest income and lowest social and professional status have the greatest difficulties in their access to ICT (Batorski, 2014, p. 370) which "three times points to seniors, who are prone to digital and, as a result, social exclusion. That is why it is necessary to undertake further actions to prevent the phenomenon of digital divide, and to critically analyse the educational methods that have been employed thus far". 
Motivation. The computer skills training for people over the age of 60 conducted by AVEC Association ${ }^{6}$ as part of the @ctive Senior project provided the opportunity to carry out research on the motivation and expectations of seniors as to such training courses, the barriers and the difficulties that they face, as well as the methodology of the training course. A diagnostic survey was used.

The research on motivation of seniors to enrol on ICT skills training courses was based on the model of educational motivation proposed by Mary Crowder and Kare Pupynin (1993). The conclusions drawn from the replies to the survey have been summarised in the form of a reconstructed sentence: "I want to communicate and to participate in the virtual world available to others. I want to achieve this by acquiring computer and Internet skills. That is why I am willing to learn by participating in a computer skills training course. Awareness of my own competences and participation in the lives of others will be my reward" (Jurczyk-Romanowska, 2012, p. 83). A detailed adaptation of the model by M. Crowder and K. Pupynin is presented in fig. 2.

On the basis of the presented model of seniors' educational motivation a computer skills training course for seniors was designed. It was based on the classroom/lesson method, in which the didactic aim is explicit, the training sessions are conducted according to previously developed lesson plans, the teacher occupies the central position in the didactic process, and the didactic programme is open and emphasised ${ }^{7}$.

The barriers. Concurrently, research on educational barriers was conducted. The barriers are understood as "various limitations and difficulties in the process of learning and self-education [...], the factors rendering it difficult or impossible to implement the idea of lifelong learning in formal, informal, and non-formal education" (Jurczyk-Romanowska, \& Zakowicz, 2015, p. 196). The barriers can be divided into objective and subjective, and the criterion of the division is the level to which they depend on the seniors' attitudes and convictions.

The objective barriers pertain, first and foremost, to the phenomenon of the ageing of the organism (the deteriorating psychological and physical condition, prolonged reaction time), attitudes of the training course instructors (improper approach to seniors, infantile attitude, lack of knowledge of the specificity of educating seniors), conditions of the education process (improper rate of work, inadequate expectations and teaching methods, inadequate learning

6 AVEC Association is a non-governmental organisation founded in 2007 by students and graduates in fields of studies related to pedagogics and psychology. Its main aim is the education of seniors to prevent their digital exclusion.

7 More on the prepared training courses: The Third Shift. Andragogical Reflections on the @ktywny Senior Project, ed. E. Jurczyk-Romanowska, UMWD, Wrocław 2012, chapters: Computer skills training course for seniors - experience gained from the @ktywny Senior project (Jacek Gulanowski), Advanced stage of the computer skills training course for seniors - introducing the participants to the world of the internet (guidelines for teachers) (Joanna Golonka), Computer and internet skills training for seniors (Joanna Golonka, Jacek Gulanowski, Ewa Jurczyk-Romanowska) 


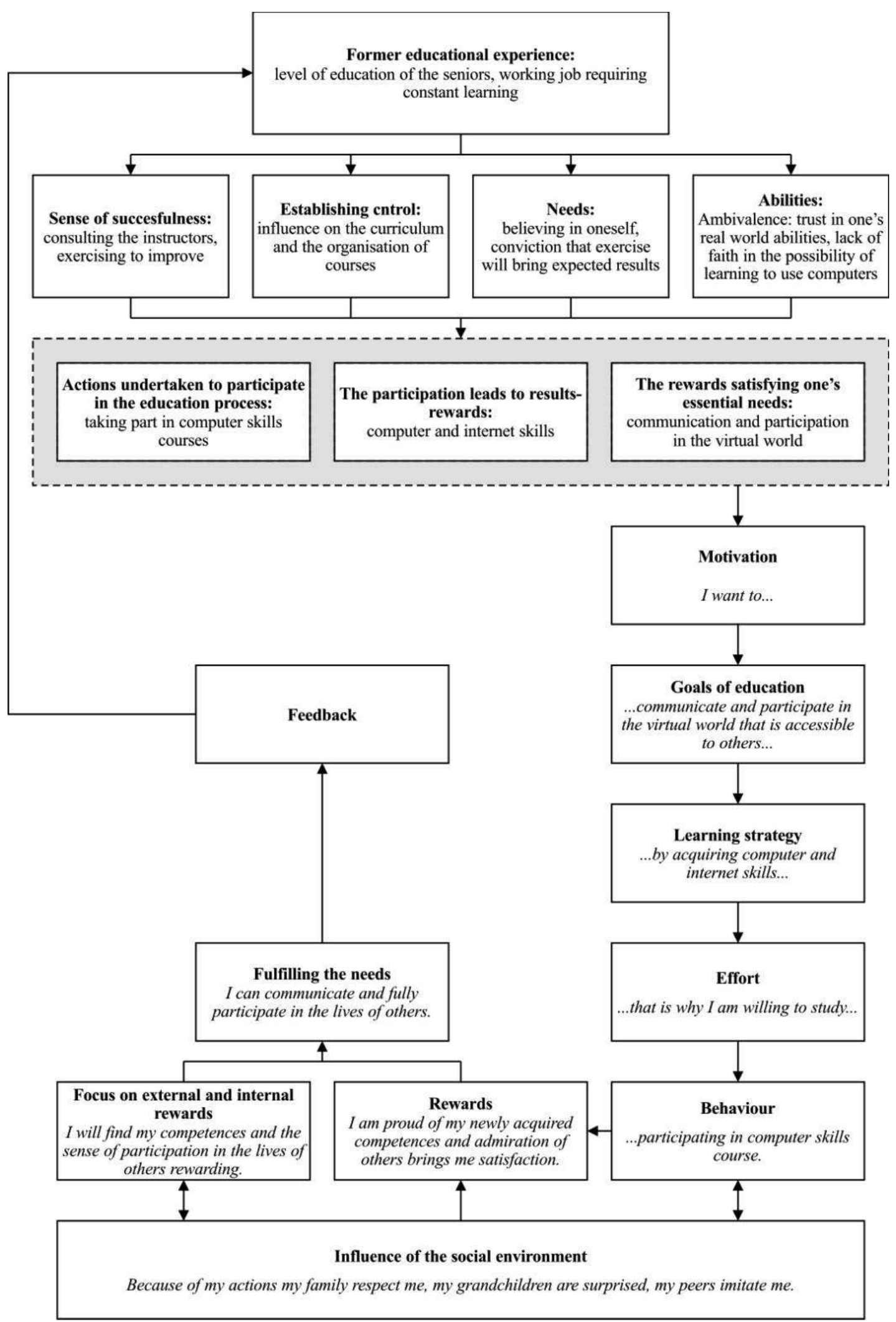

Fig. 2 An outline of the motivation in seniors' computer skills training. Source: (Jurczyk-Romanowska, 2012, p. 83). 
conditions - e.g. chairs, improper selection of teaching materials), and social and cultural changes (the teaching content not adjusted to what the seniors are interested in) (Jurczyk-Romanowska, \& Zakowicz, 2015, p. 200). Among the subjective barriers in the education of seniors, which were mentioned by the investigated seniors themselves, the following can be enumerated:

- previous negative educational experience,

- the conviction that education at this late stage in life is not necessary,

- the lack of the need to develop, to gain knowledge, the get new experiences,

- the lack of self-confidence,

- the lack of motivation,

- the lack of dedication,

- the lack of faith in one's abilities,

- the fear of change, neophobia,

- the fear of breaching the sense of security,

- the fear of failure,

- the fear of the teacher's attitude towards seniors,

- the fear of being judged, especially contrasted with others in the group (Jurczyk-Romanowska, \& Zakowicz, 2015, pp. 196-197).

In the enumeration provided by the seniors who began participating in the courses conducted with the use of the classroom/lesson method previous educational experiences, a stereotypical perception of the need of development of persons in late adulthood, and a number of fears experienced in the educational process are clearly combined. "Stresses of this kind not only bring back memories in seniors, but they also lead to defensive behaviour. On the one hand, they work as blocks, and on the other, they may be a form of defiance, which may lead to withdrawal, complaining, increased number of mistakes, irritability, conflicts, problems with memory and with the verbalisation of one's thoughts, etc." (Jurczyk-Romanowska, \& Zakowicz, 2015, p. 198). Therefore, computer skills training for people in their late adulthood ought to be designed in such a way as to avoid situations "typical of school", which lead to stress and that trigger a number of blocks that make seniors' learning difficult.

The virtual world. In relation to computer skills training yet another problem presents itself: the seniors' perception of the virtual world as "alien, strange environment in which one functions completely differently from reality" (Jurczyk-Romanowska, \& Zakowicz, 2015, p. 205). The research on the perception of the virtual world was also conducted during the @ctive Senior project before the ICT initiation of the participants of the courses. Such terms as: unreal, not real, "make-believe", utopian, "somewhere out there, something I can't see" were uttered. The seniors, when entering the digital world, had very little knowledge about it, they would mainly focus on the unreality of this alternative space. At the same time, they expressed hope that the strangeness of cyberspace was only passing and that understanding would come with the acquisition of computer and Internet skills. Apart from the mentioned abstrac- 
tion figurative associations related to outer space and fairytales were prevalent. The seniors discussed the perceived similarities between cyber and outer space, galaxies, or even some specific phenomena of the universe. Associations with the inside of a computer as well as a network of computers were less frequent (Jurczyk-Romanowska, 2015, pp. 86-88).

\section{THE IDEA OF EDUTAINMENT}

Edutainment. When attempting to find a solution alternative to the classroom/lesson method, taking into account the fact that seniors perceive cyberspace as alien, reflections were initiated on the conception of edutainment in the education of persons in their late adulthood. Edutainment combines valuable educational content with elements of entertainment, which makes it one of the most efficient methods of transferring knowledge and forming social attitudes. The successfulness of this method lies to a major extent in the informal character of the educational transfer. It is usually implicit in a form that appears attractive to the recipient. That is why the recipients may not always be aware of the fact that they are expanding their knowledge and developing their skills (Richardson, Jasmine, Hancock, \& Tellier, 2014). The research on this subject was conducted by scientists from the Games and Innovation in Education Research Team - Edutainment (Zespół Badawczy Gier i Innowacji w Edukacji - Edutainment) ${ }^{8}$.

The perception of games. Firstly, a diagnosis of the seniors' perception of games was carried out ${ }^{9} .50$ seniors aged 65+ were asked to fill in a survey of open-ended questions. The seniors belonged to groups related to education (25 students of the University of the Third Age in Wrocław) and 25 that did not (25 declared that they did not belong to any educational groups). The first regularity that was noticed during the explorations was the division into games and computer games. In the seniors' opinion, the latter have negative connotations: they are a threat, a waste of time ("a thief of time"), they are addictive, and they have a negative influence on the personality of the gamer. They are decisively seen as dedicated to young people - that is because, on the one hand, they are unfit for seniors, they require fast reactions, and their high level of details cannot be fully perceived by people in late adulthood. Seniors see computer games as full of aggression and violence. It is interesting that many of the research subjects declared that they enjoyed games such as Criminal Case or Bubble Island available on Facebook. These are often not seen as "computer" games, but merely as leisure activity. Another issue raised by seniors in rela-

8 Games and Innovation in Education Research Team - Edutainment - was founded in 2013 in the Institute of Pedagogy of the University of Wrocław. The work of the team focuses on designing and researching games dedicated to persons in their late adulthood.

9 The research on the seniors' perception of games was conducted by members of the Games and Innovation in Education Research Team - Edutainment: Ewa Jurczyk-Romanowska, Ilona Zakowicz, and Dominik Figiel. 
tion to computer games is the necessity to have advanced computer skills; as the seniors lack these skills, they avoid computer games.

In the second category created by the research subjects there were "other" games, starting with traditional card games such as bridge, various board games, jigsaw puzzles, crosswords, and riddles. Games involving movement were also mentioned. One of the seniors noted: "game has many meanings [...]. It is fun that I only associate with my childhood, playing at home, at the table, often together with my parents - some boards, cards, dice, etc. Is doing crosswords, Sudoku, playing complex solitaire, or jigsaw puzzles games? For me it is not, but I might be wrong. To me a game is entertainment for two or more people ${ }^{10}$. Other research participants noted that "non-computer" games are "something interesting, relaxing, good when you are stressed", "intellectual fun, intellectual entertainment, you can get satisfaction from solving problems", "it is a nice way to spend your time which involves emotions (elements of competition), and they are also a "confirmation of your intellectual and physical agility". When asked what game the seniors would like to participate in they mentioned logical and skill games, and games with simple rules, "adventure, action, riddles". At the same time, what was important for seniors was that the games should not only be entertaining, but also have other goals related to the quality of life of the players. Firstly, the socialising role of games was noted, because they allow one to spend time with their peers, or to establish intergenerational contacts within families. Furthermore, games allow seniors to be intellectually agile longer, they are a "workout for the mind". As the seniors wrote: "games make your brain work, your brain doesn't die like when you watch TV series"; "Riddles, intellectual games and skill games practice you thinking, perception, reflexes, they are also relaxing and fun, when you play in a team. They are all good!", "They bring a little emotion (competition, score, further levels), they practice your memory". Games can also have positive influence on health: here team competition in Nordic walking, a sport that currently enjoys great popularity as a form of physical activity that seniors can take part in. Among the disadvantages of games the possibility to become addicted was prevalent. One of the seniors stated: “The risk of addiction. I'm joking, of course, but me myself, I once burned a dinner when the crossword was particularly interesting".

Games dedicated to seniors. As the research subjects mentioned repeatedly, games for seniors ought to be adapted to their age, their abilities. This should be reflected in the size of details and fonts, which need to be larger than in the case of younger people who, as a rule, have better eyesight. What is more, they ought to take into account the slower reactions of seniors. One of the research participants noted: "Maybe this is going to sound wrong, but they should be similar to games for children - cheerful, with slow action with a longer time for reaction and with simple clear rules written for seniors". On the

10 Anonymous replies of the seniors are cited throughout the paper. 
other hand, games dedicated to people in their late adulthood can by no means be infantile. Deteriorating eyesight and physical agility ought to be taken into account, but these can never be identified with lower intellectual capabilities. Games of seniors should be based on "activating memory and leading to broader knowledge, for example, making you use encyclopaedias, the Internet, atlases. You should meet people - team games".

On the basis of the conducted research the rules for designing games for persons in their late adulthood were developed:

1. Prohibition of infantilization - the games ought to be interesting to an adult.

2. Beauty in simplicity - the graphics ought to be aesthetically pleasing and simple.

3. Respect for experience - the games ought to provide one with a chance to use their previous life experience as well as knowledge and competences.

4. Taking into account seniors' physical condition - the games ought to be proper for the seniors' health, the games should include a careful balance between challenge and accessibility.

5. Chance for development - the games need to be a combination of entertainment, education, and socialising.

6. Understandable rules - the games should have clear instructions which, when read, can be understood by persons with poor eyesight.

Location-based games as a didactic method. On the basis of an analysis of the experiences gathered in the course of the implemented educational projects in the form of computer skills training for seniors, as well as research results the members of the Games and Innovation in Education Research Team - Edutainment have attempted to adopt location-based games as an educational method. When defining the term location-based game the following elements need to be noted: (1) the condition of winning, that is, clearly defining when a game is won; (2) aim, that is, defining what the players have to achieve in order to win - typically there are a number of aims in a game to be achieved and victory is based on those; (3) action, that is, clearly defined steps that players need to take throughout the game; (4) obstacles, defined as all the difficulties that players have to face when trying to achieve their goals - this constitutes the essence of the game, because it is the source of enjoyment; (5), rules - limitations that players must respect during the game, and which, at the same time, make the game entertaining (Tkaczyk, 2012, p. 102). Furthermore, the game is played in an outlined area - urban space. This space is treated as a game board.

Adoption of location-based games as a didactic method is based in incorporating didactic aims and activities in games that are nonetheless entertaining. The term "gamification" also needs to be mentioned here. It is "defined as conscious and premeditated use of the mechanism and techniques employed in designing games in order to boost dedication and loyalty and to modify people's behaviours and habits (...). The rationale behind gamification is directing 
the participants towards a certain goal defined by the authors of a project and their motivation to take certain actions, even if these are perceived as boring and routine" (http://grywalizacja24.pl/definicje/). Following Paweł Tkaczyk it may be added that gamification is "injection of entertainment into something that was no fun previously" (Tkaczyk, 2011). Therefore, the use of the rules of location-based games and their adoption as a didactic method was aimed to move the training course out of the atmosphere of a school - which, as it is mentioned above, was connected with triggering of certain barriers in computer skills training of seniors - to a game that has been designed according to seniors' expectations. The method needed to be characterised by: competition between groups of participants, a plot developed for the game, hiding the didactic elements while at the same time emphasising the elements of the plot, rules created for the game, premeditated distracters, moving the game into urban space, giving the participants of the game the central role, and giving the educator the role of a facilitator.

Verification of the effectiveness of the location-based game method. The next step was the verification of the effectiveness of the location-based game method which was carried out by means of a pedagogical experiment. The experiment was conducted in the multimedia room in the EMPIK bookstore, in the Renoma department store in Wrocław. 57 seniors, students at Universities of the Third Age in Wrocław, took part in it.

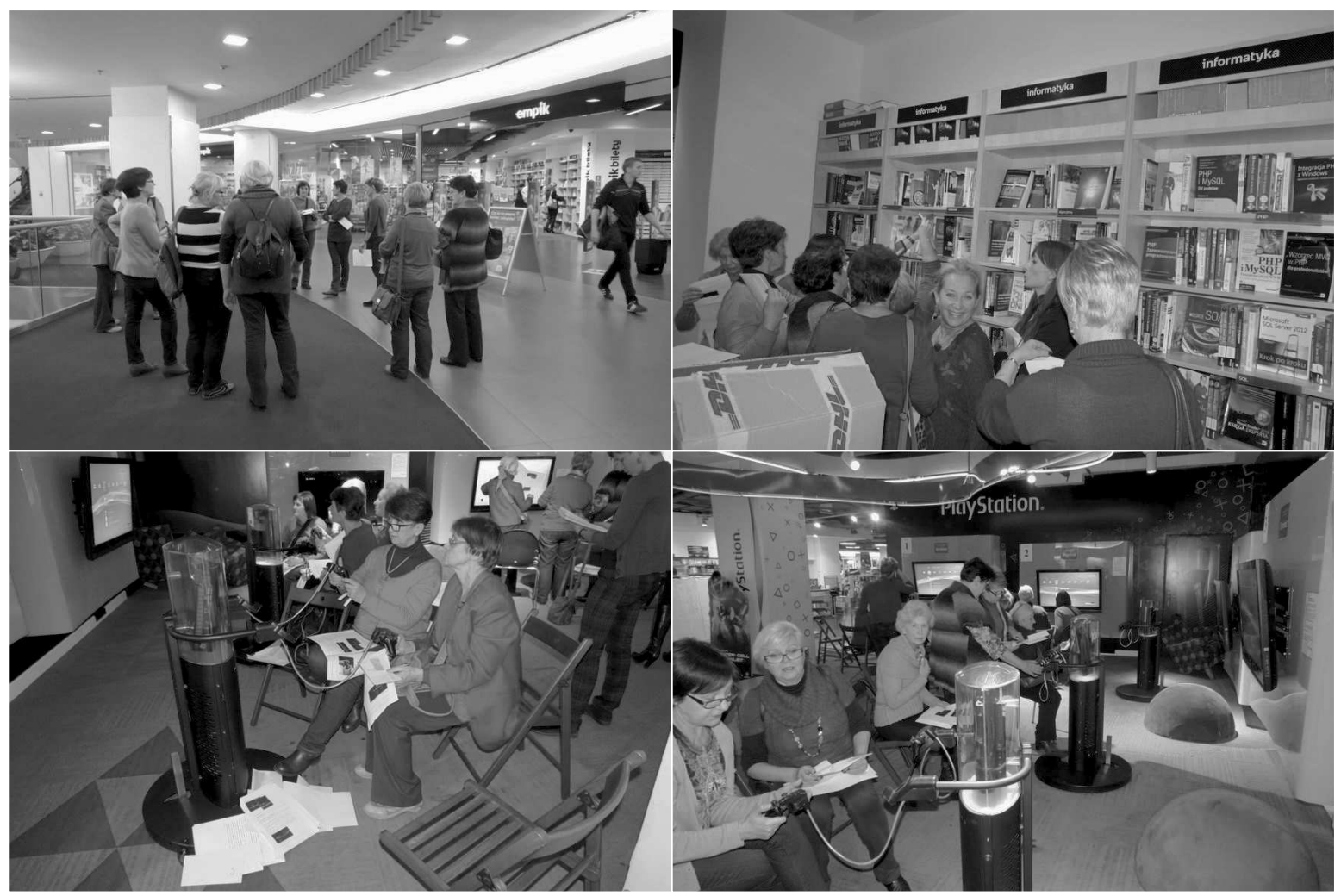

Photographs 1-4. Photographic documentation of the pedagogical experiment in the EMPIK bookstore in Wrocław; November 2013, I. Zakowicz 
The main research question set in the described pedagogical experiment was: Is teaching seniors ICT skills with the use of a location-based game more effective than with the use of the classroom/lesson method? The independent variable was the teaching method: in the experimental group the locationbased game method was employed, and in the control group the classroom/ lesson method was used. The dependent variables and the indicators are presented in the table below.

Table 1. The dependent variables and the indicators in the pedagogical experiment

\begin{tabular}{|l|l|}
\hline Dependent variable & Indicator \\
\hline The tempo of knowledge acquisition & Time needed to complete tasks \\
\hline Participants' level of independence & Number of questions asked \\
\hline Evaluation of the course & Scale of marks \\
\hline
\end{tabular}

In the location-based game method the game CyberSenior Party ${ }^{11}$ was designed. The aim within the plot was to have the seniors prepare an interesting (as interesting as possible) party for their friends. The party was to have holiday photos presentation, showing a film, and preparing a musical background to make the get-together more entertaining. Information on what the aim is, where it is to be achieved (multimedia room of the EMPIK bookstore), what the available tools are (PlayStation 3), as well as tips on how to use the devices were hidden in various locations in the EMPIK bookstore. In case of the classroom/lesson method the multimedia room was organised like a traditional classroom, the lesson was based on a presentation about the PlayStation 3 given by a teacher, and having the seniors take part in a sequence of exercises aimed to help them learn to use the device. In both the groups the time needed to complete the tasks was measured, the number of questions that the seniors asked the educators was counted, and the evaluation card was distributed after the training session.

As a result of the conducted experiment it can be stated that the teaching method has significant influence on the tempo of the acquisition of knowledge (time needed to complete the tasks) and the participants' level of independence (number of questions asked). On this basis the location-based game method was found to be more effective in ICT skills training of persons in their late adulthood than the classroom/lesson method. At the same time, the selection of the teaching method has no bearing on the seniors' evaluation of the training: both the session conducted with the use of the location-based game method, and that run with the use of the classroom/lesson method were evaluated highly. The added value was the fact that seniors who were members of the group that worked with the use of the location-based game method became interested in

11 The main author of the game is Natalia Romanowska, member of the Games and Innovation in Education Research Team - Edutainment. 
PlayStation 3 - they stayed longer in the multimedia room to explore the features of the device. (The results of the experiment have been described in detail in: Jurczyk-Romanowska, Gulanowski, Marcinkiewicz, 2014).

It ought to be noted that conducting the training session with the location based game as well as the experiment itself were not free from difficulties at various stages. During the recruitment of the participants it turned out to have been a mistake to even vaguely mention that it was the location-based game group that was being verified, because, as a result, all the seniors would ask to "sign up" for the experimental group. During the course of the experiment the participation was decreased -3 persons did not show up without prior notification. However, the evaluation of the session presented the greatest problem, because the seniors wanted to "thank" the organisers for their time by giving high marks, and they tried to "consult" the answers among themselves. What is more, two of the research participants had a number of health-related difficulties during the training. That is why it appears necessary to carry out medical qualification for location based games.

\section{CONCLUSIONS}

The idea of edutaiment can be successfully used in the education of seniors. It is compatible with the educational motivation model developed by $\mathrm{M}$. Crowder and K. Pupynin adapted to computer skills training of seniors. At the same time, using a location-based game makes it possible to avoid a number of barriers that accompany computer skills training courses and which are typical of persons in their late adulthood. Nevertheless, when designing educational games for seniors one ought to take into account the seniors' expectations and postulates.

The research in the form of pedagogical experiment makes it possible to propose the location-based game method as an alternative way of educating seniors in ICT. The presented results suggest a higher effectiveness of the tested game, which should constitute a motivation to design gamified training courses and to conduct further scientific explorations.

\section{REFERENCES}

[1] Batorski, D. (2014). Polacy wobec technologii cyfrowych - uwarunkowania dostępności i sposobów korzystania [Poles and digital technology - conditions of their access and use]. In: J. Czapiński, T. Panek (Eds.). Diagnoza społeczna 2013. Warunki i jakość życia Polaków. Raport [Social diagnosis 2013. Conditions and quality of life of Poles. A report] (pp. 317-340). Warszawa: Ministerstwo Pracy i Polityki Społecznej \& Centrum Rozwoju Zasobów Ludzkich.

[2] Crowder, M., \& Pupynin, K. (1993). The Motivation to Train: A Review of the Literature and the Development of a Comprehensive Theoretical Model of Training Motivation. Sheffield: Employment Department Group.

[3] Czapiński, J., \& Panek, T. (Eds.) (2014). Diagnoza społeczna 2013. Warunki i jakość życia Polaków. Raport [Social diagnosis 2013. Conditions and quality of life of Poles. A report]. Warszawa: Ministerstwo Pracy i Polityki Społecznej \& Centrum Rozwoju Zasobów Ludzkich. 
[4] Free On-Line Dictionary of Computing (2008). Retrieved February 12, 2016 from http:// foldoc. org/Information+and+Communication+Technology.

[5] Goban-Klas, T., \& Sienkiewicz, P. (1999). Społeczeństwo informacyjne. Szanse, zagrożenia, wyzwania [Information society. Opportunities, dangers, challenges]. Kraków: Wydawnictwo Postępu Telekomunikacji.

[6] Golonka, J. (2012). Computer skills training course for seniors - experience gained from the @ktywny Senior project. In: E. Jurczyk-Romanowska (Ed.). The Third Shift: Andragogical Reflections on the @ktywny Senior Project (pp. 97-109). Wrocław: UMWD.

[7] Gulanowski, J. (2012). Advanced stage of the computer skills training course for seniors - introducing the participants to the world of the internet (guidelines for teachers). In: E. Jurczyk-Romanowska (Ed.). The Third Shift: Andragogical Reflections on the @ktywny Senior Project (pp. 111-121). Wrocław: UMWD.

[8] Habib, J., Harris, K., Hellawell, S., Mattews, D., Percy-Smith, J., Taylor, J., \& Thompson, B., (1997). The Net Result. Social Inclusion in the Information Society, Retrieved February 12, 2016 from http:/ / www.local-level.org.uk/uploads/8/2/1/0/8210988/netresult.pdf.

[9] Definicje [Definitions]. Retrieved November 21, 2015 from http://grywalizacja24.pl/ definicje/.

[10] Jurczyk-Romanowska, E. (2015). An abstraction, outer space, a fairytale, a web, or an entanglement of cables? - cyberspace in the conception of seniors participating in information technology education. In: I. Zakowicz (Ed.). Theatre, Myth and Elderly in Education Experience (pp. 81-90). Wrocław: Fundacja Pro Scientia Publica.

[11] Jurczyk-Romanowska, E. (2012). Motivations, expectations, and postulates of seniors in their computer skills training. In: E. Jurczyk-Romanowska (Ed.). The Third Shift: Andragogical Reflections on the @ktywny Senior Project (pp. 79-96). Wrocław: UMWD.

[12] Jurczyk-Romanowska, E., Golonka, J., \& Gulanowski, J. (2012). Computer and Internet skills training - lesson plans. In: E. Jurczyk-Romanowska (Ed.). The Third Shift: Andragogical Reflections on the @ktywny Senior Project (pp. 123-147). Wrocław: UMWD.

[13] Jurczyk-Romanowska, E., Gulanowski, J., Marcinkiewicz, A. (2014). The effect of locationbased game on the learning of seniors in the field of information and communications technologies. Mediterranean Journal of Social Sciences 5(19). 396-404. doi: 10.5901/mjss.2014. v5n19p396.

[14] Jurczyk-Romanowska, E., \& Zakowicz, I. (2015). Bariery w uczeniu się osób starszych na przykładzie edukacji informatycznej [Barriers in seniors learning as exemplified by computer skills training]. In: A. Haratyk, N. Zayachkivska (Eds.). Rozwój polskiej i ukraińskiej teorii i praktyki pedagogicznej na przestrzeni XIX - XX wieku. Edukacja dorostych w Polsce i na Ukrainie (XIX-XX w.) [Development of Polish and Ukrainian pedagogical theory and practice in the $19^{\text {th }}$ and the $20^{\text {th }}$ century. Adult education in Poland and in the Ukraine (19 ${ }^{\text {th }}-20^{\text {th }}$ century)] (pp. 195-207). Wrocław: Oficyna Wydawnicza ATUT \& Wrocławskie Wydawnictwo Oświatowe.

[15] Mead, M. (2000). Kultura i tożsamość [Culture and Identity]. Warszawa: PWN.

[16] Murray, J. (2011). Cloud network architecture and ICT, retrieved February 12, 2016 from http://itknowledgeexchange.techtarget.com/modern-network-architecture/cloud-network-architecture-and-ict/.

[17] Richardson, J.T., Jasmine, A., Hancock, L., \& Tellier, S. (2014). Raise 5 Edutainment: Effectively educating while entertaining to reduce substance abuse and HIV risky behaviors among AfricanAmerican college students. Conference: 142nd APHA Annual Meeting and Exposition.

[18] Tkaczyk, P. (2012). Grywalizacja [Gamification]. Gliwice: Hellion.

[19] Tkaczyk, P., (2011). Kiedy grywalizacja nie zadziała? [When does gamification fail?]. Retrieved November 21, 2015 from http://pl.paweltkaczyk.com/kiedy-grywalizacja-nie-zadziala/.

[20] Weber, M. (2009). October 29, 1969: Happy 40th Birthday to a Radical Idea!, Retrieved April 2, 2014 from http://www.computerhistory.org/atchm/october-29-1969-happy -40th-birthday-to-a-radical-idea/. 